\title{
Passive Immunization
}

National Cancer Institute

\section{Source}

National Cancer Institute. Passive Immunization. NCI Thesaurus. Code C15259.

The conference of active humoral immunity from one individual to another via the transfer of formed antibodies. 